\title{
Kompetensi Peserta Pelatihan Sebelum dan Saat Masa Pandemi Covid-19: Studi Kasus Latsar CPNS
}

\section{Participants' Competencies Before And During Covid-19 Pandemic: Study On Basic Training Of Prospective Civil Servants}

\author{
Putri Wulandari Atur Rejeki ${ }^{1}$, Yuyu Yuningsih ${ }^{2}$ \\ Pusat Pelatihan dan Pengembangan dan Pemetaan Kompetensi Aparatur Sipil Negara LAN \\ RI, Jl. Kiara Payung km. 4,7 Bumi Perkemahan Jatinangor Sumedang Jawa Barat \\ putriwulandari37@gmail.com
}

Naskah diterima tanggal 13 April 2021. Naskah direvisi tanggal 15 Juni 2021. Naskah disetujui tanggal 16 Juni 2021.

\begin{abstract}
Abstrak
Perkembangan teknologi membuat penyelenggaraan pendidikan dan pelatihan mengalami perubahan yang cukup signifikan, terutama di masa pandemi Covid-19. Pelatihan yang semula diselenggarakan secara tatap muka berubah menjadi non-tatap muka dengan metode e-learning. Hal ini tentu saja dapat memengaruhi hasil kompetensi peserta pelatihan. Penelitian ini bertujuan untuk memberikan gambaran terkait kompetensi peserta Pelatihan Dasar Calon Pegawai Negeri Sipil (Latsar CPNS) sebelum dan pada saat pandemi Covid19. Metode penelitian yang digunakan adalah metode kuantitatif. Populasi penelitian ini adalah seluruh peserta Latsar CPNS Golongan III yang mengikuti pelatihan di Puslatbang PKASN LAN pada periode 2019 - 2020. Data yang digunakan adalah data sekunder dari database Puslatbang PKASN LAN mengenai nilai hasil evaluasi peserta Latsar CPNS, yaitu evaluasi akademik, evaluasi aktualisasi, evaluasi sikap dan perilaku, serta evaluasi kompetensi teknis bidang tugas. Data diolah menggunakan program SPSS versi 23 yang selanjutnya dianalisis menggunakan uji Mann-Whitney. Hasil penelitian menunjukkan bahwa terdapat perbedaan kompetensi peserta Latsar CPNS sebelum dan pada saat pandemi Covid-19 secara signifikan. Beberapa upaya yang dapat dilakukan untuk memaksimalkan peningkatan dan pengembangan kompetensi peserta pelatihan diantaranya yaitu instansi penyelenggara pelatihan harus memperhatikan seluruh aspek penyelenggaraan pelatihan dengan metode e-learning. Aspek-aspek tersebut diantaranya yaitu konten/materi pembelajaran, strategi pembelajaran, sarana dan prasarana serta SDM terkait penyelenggaraan pelatihan.
\end{abstract}

Kata Kunci: Pelatihan; Kompetensi; Pandemi Covid-19; Latsar CPNS

\section{Abstract}

The development of technology that implemented in education and training made significant changes, especially during the Covid-19 pandemic. The training, which was held classically has turned into non-classical with the e-learning method. This of course can affect the 
competency results of the training participants. This study aims to provide an overview of participants' competencies in the Basic Training of Prospective Civil Servants (Latsar CPNS) before and during the Covid-19 pandemic. The research method used is quantitative. The population of this study was all of Latsar CPNS participants type III who attended the training in Puslatbang PKASN LAN in 2019 - 2020. The data used are secondary data from the Puslatbang PKASN LAN database regarding the evaluation results of Latsar CPNS participants i.e academic evaluation, actualization evaluation, attitude and behavior evaluation, and evaluation of technical competence in the field of duty. The data were processed using the SPSS version 23 program, then analyzed using the Mann-Whitney test. The results showed that there are significant differences in the competence of Latsar CPNS participants before and during the Covid-19 pandemic. Therefore, several efforts could be made to maximize the improvement and development of the competence of training participants, including training providers who must pay attention to all aspects related to the implementation of e-learning method. These aspects include the content/learning materials, learning strategies, facilities, infrastructure, and human resources related with the training.

Keywords: Training; Competencies; Covid-19 Pandemic; Apparatus

\section{PENDAHULUAN}

\section{Latar Belakang}

Pandemi Covid-19 yang melanda sejak awal tahun 2020 memiliki dampak yang sangat besar bagi masyarakat global, termasuk Indonesia. Yang paling nyata, virus ini telah mengubah tata cara manusia dalam menjalani berbagai macam aktivitasnya dalam kehidupan sehari-hari. Sejak virus ini mewabah, seluruh kegiatan di tempat umum dibatasi bahkan dilarang beroperasi. Pemberlakuan physical distancing dilakukan pemerintah dalam upaya menekan penyebaran virus Covid-19 (Mustaqin \& Fahrina, 2020; Syarifuddin, 2020).

Salah satu sektor yang terkena dampak cukup signifikan akibat Pandemi Covid-19 adalah pendidikan dan pelatihan (Erni et al., 2020; Martoredjo, 2020; Pujilestari, 2020). Proses pembelajaran yang semula dilaksanakan tatap muka secara langsung (klasikal) digantikan dengan pembelajaran secara dalam jaringan (daring atau e-learning). Pembelajaran daring tidak hanya dilakukan pada tingkat pendidikan dasar, menengah, maupun tingkat perguruan tinggi, tapi juga dilakukan dalam dunia pelatihan secara umum. Salah satunya adalah Pelatihan Dasar Calon Pegawai Negeri Sipil (Latsar CPNS).

Sejak tahun 2019, penyelenggaraan kegiatan Latsar CPNS telah dibarengi dengan metode e-learning. Metode e-learning ini dilakukan melalui penggunaan Learning Management System (LMS) yang dimiliki oleh penyelenggara pelatihan, namun terbatas hanya pada agenda tertentu, dengan waktu pembelajaran tertentu pula. Biasanya e-learning dilakukan pada malam hari setelah pembelajaran tatap muka selesai. Dengan adanya 
pandemi Covid-19, penyelenggaraan Latsar CPNS mengalami penyesuaian. Sesuai dengan Surat Edaran Kepala Lembaga Administrasi Negara No. 10/K.1/HKM.02.3/2020 tanggal 23 Maret 2020 Tentang Panduan Teknis Penyelenggaraan Pelatihan dalam Masa Pandemi Covid-19, penyelenggara pelatihan harus menyesuaikan teknis pelatihan. Penyesuaian yang dilakukan diantaranya berkaitan dengan proses pembelajaran. Proses pembelajaran yang semula dilakukan secara klasikal (tatap muka) berubah menjadi non-klasikal dengan metode distance learning. Pada masa pandemi Covid-19, porsi e-learning pada penyelenggaraan Latsar CPNS menjadi lebih banyak dibandingkan dengan tatap muka.

E-learning sendiri merupakan upaya pendistribusian pembelajaran melalui media elektronik atau internet. Dengan e-learning, setiap orang dapat mengakses materi kapanpun dan dimanapun mereka berada (Karwati, 2014; Kusmana, 2011; Mutia \& Leonard, 2013; Nadziroh, 2017; I. Suartama, 2019; I. K. Suartama, 2014). E-learning memberikan berbagai macam manfaat. Pertama e-learning dapat mempersingkat waktu pembelajaran dan membuat biaya studi lebih ekonomis. Kedua e-learning mempermudah akses peserta didik dengan bahan materi. Manfaat yang ketiga adalah peserta didik dapat saling berbagi informasi dan dapat mengakses bahan-bahan belajar setiap saat dan berulang-ulang. Dengan kondisi demikian peserta didik dapat lebih memantapkan penguasaannya terhadap materi pembelajaran. Manfaat keempat adalah proses pengembangan pengetahuan tidak hanya terjadi dalam ruang kelas saja, akan tetapi dengan bantuan peralatan komputer dan jaringan, peserta didik dapat secara aktif dilibatkan dalam proses belajar-mengajar (Rohmah dalam Hartanto, (2016)). Manfaat lain dari e-learning adalah terbentuknya budaya semangat belajar. Melalui e-learning akan mendorong timbulnya ekspresi untuk mau belajar menggali pengetahuan dan informasi sendiri secara lebih aktif (Divayana, 2017).

Apabila dilihat berdasarkan nilai efektivitasnya, Munajatisari (2014) menyatakan adanya efektivitas dan efisiensi dalam penyelenggaraan program pelatihan dengan $e$ learning. Berdasarkan evaluasi yang telah dilakukan, reaksi positif dari peserta pelatihan dengan metode pelatihan e-learning lebih tinggi daripada peserta pelatihan dengan metode tatap muka. Hal ini terjadi salah satunya karena waktu yang fleksibel pada saat mempelajari materi pelatihan secara e-learning. Namun, bertolak belakang dengan hal tersebut, Nadziroh (2017) justru menyimpulkan bahwa pembelajaran melalui e-learning dinilai belum sepenuhnya efektif dalam meningkatkan pembelajaran. Hal ini dikarenakan dalam proses pengaplikasian e-learning membutuhkan koneksi internet yang stabil agar dapat berjalan 
lancar. Dari sisi pengajarpun, belum sepenuhnya pengajar menguasai pengoperasian $e$ learning.

Apabila dikaitkan dengan kompetensi dan hasil pembelajaran, Karwati (2014) menyatakan bahwa pembelajaran e-learning berpengaruh positif dan signifikan terhadap kualitas pembelajaran. Namun hasil penelitian yang dilakukan oleh Munajatisari (2014) menunjukkan hal yang berbeda. Metode e-learning memberikan hasil yang lebih rendah dibandingkan dengan metode tatap muka. Salah satu penyebabnya adalah karena ketidaktepatan penggunaan teknik penyampaian materi oleh fasilitator. Hal senada dinyatakan oleh Kusmiati \& Rahadi (2020) yang menyatakan bahwa kompetensi mahasiswa menurun dikarenakan pembelajaran dilakukan secara e-learning pada saat Pandemi Covid19. Hal ini disebabkan karena tidak sejalan atau tidak seimbangnya proses pembelajaran teori dengan praktek.

Kaitannya dengan Latsar CPNS, belum banyak penelitian yang secara khusus membahas mengenai kompetensi peserta Latsar CPNS sebelum dan pada masa Pandemi Covid-19. Oleh karena itu, penelitian ini dilakukan untuk menganalisis dua hal sebagai berikut: Pertama, bagaimana kompetensi peserta Latsar CPNS sebelum dan pada masa Pandemi Covid-19. Kedua, apakah terjadi perbedaan kompetensi antara peserta Latsar CPNS yang diselenggarakan sebelum pandemi dan pada saat Pandemi Covid-19.

\section{Rumusan Masalah}

Berdasarkan latar belakang yang telah diuraikan, maka rumusan masalah dalam penelitian ini adalah:

1. Bagaimana kompetensi peserta pelatihan sebelum masa pandemi covid-19

2. Bagaimana kompetensi peserta pelatihan pada saat masa pandemi covid-19

3. Apakah terdapat perbedaan kompetensi antara peserta pelatihan sebelum masa pandemi covid-19 dengan pada saat pandemi covid-19

\section{Tujuan dan Manfaat}

Penelitian terkait kompetensi peserta pelatihan telah banyak dilakukan. Namun, penelitian yang mengkaji secara khusus mengenai perbandingan kompetensi peserta pelatihan aparatur, khususnya Latsar CPNS, sebelum dan pada saat pandemi covid-19 belum banyak dilakukan. Oleh karena itu, tujuan dan manfaat penelitian ini yaitu: 
1. Mengetahui kompetensi peserta pelatihan dasar CPNS sebelum masa pandemi

2. Mengetahui kompetensi peserta pelatihan dasar CPNS pada masa pandemi covid-19

3. Mengetahui apakah terdapat perbedaan kompetensi antara peserta pelatihan sebelum dan pada saat masa pandemi covid-19

\section{LANDASAN TEORI}

\section{Kompetensi}

Sumber Daya Manusia (SDM) merupakan resources yang paling strategis dan merupakan investasi terpenting yang harus dilakukan oleh suatu organisasi (Abdussamad, 2017). SDM yang berkualitas merupakan prasyarat dalam meningkatkan mutu penyelenggaraan negara serta pelayanan pemerintah kepada masyarakat. Oleh karena itu, organisasi harus memiliki strategi dan program pengembangan kompetensi SDM yang tepat dan sesuai kebutuhan. Kompetensi SDM yang mumpuni akan meningkatkan kinerja organisasi dan meningkatkan kualitas pelayanan (Abdussamad, 2017) .

Secara umum, kompetensi diartikan sebagai kombinasi antara tingkat keterampilan/keahlian (skill), pengetahuan (knowledge) dan tingkah laku (attitude) yang dimiliki oleh seorang individu dalam melaksanakan tugas yang ditekankan kepadanya dalam organisasi. Kompetensi juga diartikan sebagai kemampuan individual untuk mengerjakan berbagai tugas dan menunjukkan hasil kerjanya sesuai dengan standar dan secara memuaskan bedasarkan tugas dan kriteria yang jelas (Abdussamad, 2017; Anwaruddin, 2006; Day, 2017; Efendi, 2015; Faisal et al., 2020; Fathurrochman, 2017; Gardiner \& Riecmann, 2015; Kusmiati \& Rahadi, 2020).

Menurut Hassan \& Varshosaz (2016), skill merupakan area yang sangat beragam sehingga sulit didefinisikan. Akan tetapi, skill adalah kemampuan yang bisa membawa kesuksesan dengan rasa percaya diri tertentu dan dengan menghabiskan tenaga dan waktu kerja yang minimal. Knowledge merupakan kesadaran yang menuntun pada tindakan dalam kehidupan sehari-hari dan kehidupan tersebut menunjukkan dirinya sebagai fakta yang diinterpretasikan oleh manusia dan pengetahuan merupakan dunia yang saling terkait dan koheren yang bermakna secara mental bagi mereka. Attitude adalah metode yang relatif tetap dalam pikiran, perasaan dan perilaku terhadap individu, kelompok dan masalah sosial atau lingkungan. Attitude merupakan struktur hipotesis, karena tidak terlihat secara langsung namun pada umumnya dikaitkan dengan perilaku dan ucapan verbal. Lebih lanjut Hassan \& 


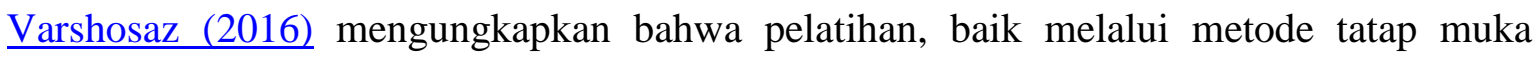
maupun kooperatif, terbukti meningkatkan pengetahuan dan tingkah laku pegawai. Walaupun pelatihan secara tatap muka tidak menunjukkan perubahan skill namun pelatihan koopratif sebaliknya. Hal ini bisa saja tergantung dari jenis pelatihan yang diselenggarakan.

Gardiner \& Riecmann (2015) mengungkapkan bahwa banyak sub-klasifikasi yang membedakan tipe kompetensi seperti kognitif (knowing that), fungsional (knowing how), dan sosial (working with groups). Hal ini sejalan dengan apa yang disampaikan oleh Day (2017) yang menyebutkan bahwa kompetensi meliputi dimensi intelektual, kognitif dan sikap serta kinerja. Kompetensi berbeda dengan kapabilitas. Kompetensi lebih menekankan kepada fungsi, dimana pengetahuan, kognitif, interaktif, afektif, perilaku dan nilai-nilai yang dimiliki seseorang memengaruhi pengerjaan tugas dan pemecahan masalah. Kompetensi berfungsi secara efektif dalam profesi tertentu, organisasi tertentu serta peran dan posisi tertentu. Kapabilitas berfokus pada keadaan atau status seseorang, yang membedakannya dari "komoditas" yang membantu menghasilkan keadaan/status tersebut dan "utilitas" yang dihasilkan oleh keadaan/status tersebut.

Efendi (2015) menyatakan bahwa kompetensi merupakan suatu perilaku yang dapat diobservasi dan diukur. Model kompetensi menggambarkan kombinasi perilaku antara pengetahuan, keterampilan dan pengalaman dengan karakteristik yang diperlukan untuk menunjukkan perannya dalam organisasi secara efektif dan kinerja yang sesuai dalam organisasi. Kompetensi ibarat gunung es di mana yang terlihat di permukaan yaitu perilaku seseorang sedangkan di bawah permukaan terdapat potensi yang sangat besar yang dapat menentukan kompetensi sesungguhnya yang dimiliki seseorang (Efendi, 2015; Faisal et al., 2020; Kusmiati \& Rahadi, 2020). Fenomena ini dapat digambarkan melalui piramida kompetensi sebagai berikut: 


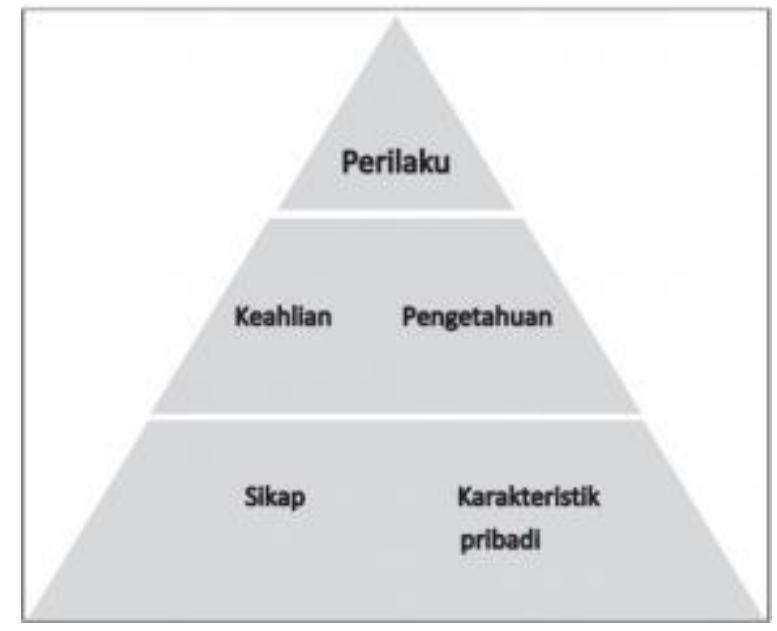

Gambar 1. Piramida Kompetensi

Kompetensi menurut Rotwel dalam Abdussamad (2017) dibagi menjadi empat yakni kompetensi teknis, kompetensi manajerial, kompetensi sosial, dan kompetensi intelektual/stratejik. Kompetensi teknis merupakan kompetensi mengenai bidang yang menjadi tugas pokok organisasi. Kompetensi manajerial yaitu kompetensi yang berhubungan dengan berbagai kemampuan manjerial yang dibutuhkan dalam menangani tugas-tugas organisasi. Kompetensi sosial yaitu kemampuan melakukan komunikasi yang dibutuhkan oleh organisasi dalam pelaksanaan tugas pokoknya. Sementara kompetensi intelektual/stratejik adalah kemampuan untuk berpikir stratejik dengan visi jauh ke depan.

Selanjutnya Abdussamad (2017) mengungkapkan bahwa terdapat empat jenis kompetensi, yaitu kompetensi pribadi, kompetensi kerja, kompetensi generik (umum), dan kompetensi permulaan dan pelaksanaan. Pertama kompetensi pribadi yaitu tingkah laku yang mendasari karakteristik individu yang dibawa ke dalam pekerjaan mereka. Kompetensi pribadi terdiri dari beberapa karakteristik sebagai keterampilan pribadi, kepemimpinan, keterampilan analitikal dan orientasi pribadi. Jenis kompetensi ini digunakan dalam proses pelaksanaan manajemen, seleksi dan pengembangan.

Kedua, kompetensi kerja adalah kompetensi yang mengarahkan pada pengharapan pelaksanaan pekerjaan dan standar produktifitas yang dikhususkan kepada pegawai untuk diharapkan dapat tercapai. Hal ini diperoleh dari tingkah laku eksplisit atau pernyataan yang berdasarkan pada hasil. Ketiga, kompetensi generik (umum). Kompetensi dapat menjadi generik secara merata jika diterapkan pada semua orang pada bidang tertentu, seperti manajemen terlepas pada organisasi tempat mereka bekerja. Semuanya dapat 
diorganisasikan secara umum dan diterapkan pada semua staf (kompetensi inti) atau berfokus pada pekerjaan khusus atau kategori pegawai seperti manajer, dokter gigi, staf profesional atau staf administrasi. Keempat, kompetensi permulaan dan pelaksanaan. Kompetensi permulaan adalah kompetensi dasar yang dibutuhkan untuk melaksanakan tugas dengan tidak membedakan antara pekerjaan level tinggi dan rendah. Sementara kompetensi pelaksanaan adalah kompetensi yang membuat perbedaannya.

Kompetensi berfungsi sebagai acuan dalam rangka seleksi, kompensasi, observasi/coaching, penilaian kinerja, penyelarasan organisasi, perencanaan karir, perencanaan suksesi dan promosi atau penempatan kerja. Standar kompetensi harus ditetapkan oleh organisasi agar setiap SDM memiliki acuan yang jelas dalam lima karakteristik kompetensi, yaitu motif, sifat/karakter, konsep pribadi, pengetahuan dan keterampilan. Kinerja seseorang dipengaruhi oleh kemampuan dan karakteristik individu yang bersumber dari salah satu atau kombinasi dari kelima karakteristik kompetensi tersebut. Penetapan standar kompetensi akan mempertegas dan memperjelas kualifikasi dalam melaksanakan tugas dan tanggung jawabnya sesuai dengan kompetensi yang dimiliki. (Abdussamad, 2017; Anwaruddin, 2006).

\section{Pengembangan Kompetensi}

Kompetensi seseorang harus selalu ditingkatkan dan/atau dikembangkan, bahkan ketika suatu organisasi menghadapi banyak permasalahan atau kesulitan (Abdussamad, 2017). Pengembangan kompetensi merupakan salah satu upaya untuk meningkatkan kompetensi melalui peningkatan pengetahuan, keterampilan dan sikap perilaku dalam menghadapi dinamika kerja sesuai dengan kebutuhan (Faisal et al., 2020). Peningkatan kompetensi pegawai akan terlihat pada perubahan keterampilan, sikap dan perilaku dalam bekerja yang pada akhirnya akan berdampak positif pada peningkatan kinerja organisasi (Efendi, 2015).

Pengembangan adalah ukuran keberhasilan pencapaian tujuan organisasi (Faisal et al., 2020). Oleh karenanya, organisasi harus selalu melakukan pengembangan pada berbagai aspek organisasi, salah satunya yaitu pengembangan kompetensi SDM yang dimiliki. Anwaruddin (2006) mengungkapkan bahwa secara praktis, pengembangan kompetensi pegawai perlu dilakukan sejak dini. Terdapat enam langkah yang dapat dilakukan untuk mengembangkan kompetensi. Pertama, mempelajari kembali tujuan organisasi untuk menentukan arah dan rancangan pengembangan kompetensi. 
Kedua, mengamati para pegawai yang perlu dikembangkan, berdasarkan pada informasi tentang latar belakang dan kualifikasi mereka dan kejelasan arah organisasi ke depan. Ketiga, menentukan bentuk pengembangan kompetensi yang diperlukan bagi para pegawai yang terpilih untuk mengisi kebutuhan organisasi saat ini dan ke depan. Keempat, menentukan kebutuhan pengembangan kompetensi individual pegawai, peningkatan keterampilan, perubahan sikap dan perilaku atau penguasaan ilmu pengetahuan. Kelima, menentukan metode pengembangan kompetensi yang paling tepat sesuai kondisi individual pegawai, kompetensi yang sekarang dimiliki atau bentuk tanggung jawab yang akan dipikulnya di masa mendatang. Terakhir, mengevaluasi proses pengembangan kompetensi yang ditempuh pegawai atau pejabat. Apakah terjadi perubahan sikap dan perilaku atau peningkatan pada keterampilan tertentu. Hal ini untuk memutuskan apakah suatu program pengembangan kompetensi terus dilanjutkan, perlu diperbaiki atau diganti dengan program lainnya.

Pengembangan kompetensi merupakan salah satu usaha meningkatkan kemampuan teknis, teoritis, konseptual dan moral pegawai sesuai dengan kebutuhan jabatan (Momor et al., 2020). Salah satu bentuk pengembangan kompetensi ini yaitu pendidikan dan pelatihan (pelatihan). Pelatihan memberikan kontribusi pada peningkatan produktivitas, efektivitas dan efisiensi serta kinerja organisasi (Fathurrochman, 2017; Momor et al., 2020).

Pelatihan harus diberikan secara berkala agar kompetensi terpelihara. Oleh karena itu, perencanaan kebutuhan pelatihan menjadi suatu hal yang penting. Lebih lanjut Fathurrochman (2017) mengemukakan bahwa program pelatihan pada umumnya dilakukan melalui metode off the job training dan on the job training. Metode off the job training merupakan pendekatan pelatihan yang dilakukan di luar tempat kerja dan metode on the job training merupakan pendekatan pelatihan yang diberikan di tempat kerja.

Metode off the job training dilakukan dalam bentuk pelatihan yang diselenggarakan di tempat pemusatan pelatihan pegawai seperti Badan Pelatihan atau Pusat Pelatihan atau Pusat Pengembangan Pegawai. Program pengembangan yang dilakukan diantaranya yaitu: (1) executive development programme; (2) laboratory training; dan (3) organizational development. Pada metode ini, pegawai memiliki kesempatan untuk keluar dari rutinitas pekerjaan dan berkonsentrasi dalam mengikuti pelatihan.

Metode on the job training dibagi menjadi 13 macam yaitu:

1. vestibule training, untuk mengajarkan keahlian kerja khusus; 
2. lecture, yaitu ceramah;

3. independent self-study, dengan membaca buku, majalah, dll;

4. visual presentations, dengan menonton $\mathrm{tv}$, film, video, atau presentasi;

5. conference discussion, misalnya pelatihan tentang pengambilan keputusan;

6. teleconferencing, online dengan menggunakan satelit/internet;

7. Case studies, dengan menganalisa masalah;

8. role-play, dengan bermain peran seolah-olah peserta terlibat langsung dalam menghadapi permasalahan;

9. simulation, untuk belajar secara teknikal dan motor skill;

10. programmed instruction, dengan menggunakan aplikasi komputer;

11. computer-based training;

12. laboratory training, dengan membentuk kelompok diskusi;

13. programme group exercise. Dengan metode ini, pegawai belajar langsung dengan menyesuaikan metode kerja, beradaptasi dengan pekerjaan mereka dan belajar dari pegawai yang lain. Metode ini berfokus pada pengembangan jangka panjang.

Menurut Lembaga Administrasi Negara (2018) dalam Peraturan LAN No. 10 Tahun 2018 tentang Pengembangan Kompetensi Pegawai Negeri Sipil (PNS), bentuk pengembangan kompetensi terbagi menjadi dua yaitu pendidikan dan/atau pelatihan. Bentuk pendidikan dilakukan dengan pemberian tugas belajar pada pendidikan formal dalam jenjang pendidikan tinggi sedangkan bentuk pelatihan dilakukan dalam bentuk pelatihan tatap muka dan pelatihan non-tatap muka.

Bentuk pelatihan tatap muka dilakukan melalui kegiatan yang menekankan pada proses pembelajaran tatap muka di dalam kelas yang sedikitnya dilakukan melalui jalur pelatihan struktural kepemimpinan, pelatihan manajerial, pelatihan teknis, pelatihan fungsional dan pelatihan sosial kultural, seminar/konferensi/sarasehan, workshop atau lokakarya, kursus, penataran, bimbingan teknis, sosialisasi dan atau jalur pengembangan kompetensi dalam bentuk pelatihan tatap muka lainnya. Bentuk pelatihan non-tatap muka dilakukan paling sedikit melalui jalur coaching, mentoring, e-learning, pelatihan jarak jauh, detasering, pembelajaran alam terbuka (outbond), patok banding (benchmarking), pertukaran antara PNS dengan pegawai swasta/BUMN/BUMD, belajar mandiri, komunitas belajar, bimbingan di tempat kerja, magang dan jalur non-tatap muka lainnya.

Pelatihan struktural kepemimpinan terdiri dari Pelatihan Kepemimpinan Nasional 
Tingkat I (PKN Tk. I), Pelatihan Kepemimpinan Nasional Tingkat II (PKN Tk. II), Pelatihan Kepemimpinan Administrator (PKA), Pelatihan Kepemimpinan Pengawas (PKP), Pelatihan Dasar Calon Pegawai Negeri Sipil (Latsar CPNS) dan Pendidikan dan Pelatihan Prajabatan Calon Pegawai Negeri Sipil Golongan I, Golongan II dan/atau Golongan III yang diangkat dari tenaga honorer Kategori 1 dan/atau Kategori 2 (Diklat Prajab CPNS).

Di organisasi publik, pelatihan Jabatan PNS bertujuan untuk meningkatkan pengetahuan, keahlian, keterampilan dan sikap untuk dapat melaksanakan tugas jabatan secara profesional dengan dilandasi kepribadian dan etika PNS sesuai dengan kebutuhan instansi; menciptakan aparatur yang mampu berperan sebagai pembaharu dan perekat dan kesatuan bangsa; memantapkan sikap dan semangat pengabdian yang berorientasi kepada pelayanan, pengayoman dan pemberdayaan masyarakat; dan menciptakan kesamaan visi dan dinamika pola pikir dalam melaksanakan tugas pemerintahan umum dan pembangunan demi terwujudnya kepemerintahan yang baik (Abdussamad, 2017; Anwaruddin, 2006).

\section{Metode Pembelajaran: Tatap muka dan e-learning}

Penyelenggaraan pembelajaran biasanya dilaksanakan secara tatap muka. Pembelajaran secara tatap muka seringkali berfokus pada pengajar yang mengikuti desain terstruktur (Kiemer et al., 2018). Pembelajaran tatap muka ini menyediakan konteks sosial yang suportif dengan cara berbagi tanggung jawab saat proses pembelajaran dan berbagi kontrol saat proses berfikir yang menumbuhkan pemenuhan kebutuhan psikologi dasar yaitu otonomi dan kompetensi. Otonomi dilihat dari kebebasan pelajar untuk menentukan perilaku mereka dan pengajar yang memiliki kewenangan penuh dalam menghadapi situasi yang terjadi di kelas. Kompetensi mengacu pada dikomunikasikannya ekspektasi pengajar akan tujuan pembelajaran, proses pembelajaran, pedoman pembelajaran, dan mengoptimalkan proses umpan balik dan tantangan.

Lebih lanjut Kiemer et al. (2018) mengungkapkan bahwa pada pembelajaran secara tatap muka, biasanya interaksi belajar-mengajar yang paling sering adalah percakapan singkat. Pembelajaran tatap muka sangat asimetris di mana peran pengajar dominan yaitu sebagai pemrakarsa dan pengontrol interaksi. Interaksi antar siswa jarang terjadi dan hanya digunakan sebagai variasi. Pembelajaran tatap muka dirasakan kurang berfungsi dalam pengembangan pemahaman pelajar secara dalam dan juga memengaruhi motivasi pelajar. 
Hal ini bisa diatasi dengan metode kelas produktif, di mana pengajar ditantang untuk mendesain aktivitas belajar yang dapat menumbuhkembangkan kompetensi pelajar.

Dengan perkembangan teknologi yang semakin pesat ditambah lagi dengan momentum Pandemi Covid-19 ini, maka penyelenggaraan pembelajaran banyak dilaksanakan dengan metode e-learning yang tidak lagi dibatasi oleh kelas-kelas secara tradisional dan tidak membutuhkan kehadiran secara fisik (Uppal et al., 2018). Konsep elearning dimaksudkan sebagai upaya pendistribusian pembelajaran melalui media elektronik atau internet sehingga setiap orang dapat mengaksesnya kapan saja dan di mana saja dari seluruh penjuru dunia. E-learning merupakan pendekatan belajar-mengajar melalui penggunaan media dan perangkat elektronik sebagai alat untuk meningkatkan akses terhadap pelatihan, komunikasi dan interaksi serta memfasilitasi adopsi cara-cara baru dalam pemahaman dan pengembangan belajar (Alhabeeb \& Rowley, 2018).

E-learning biasa disebut pula dengan istilah online learning, virtual learning, internet-enabled learning, distributed learning, networked atau web-based learning yang semuanya mengacu pada makna yang sama (Karwati, 2014; Mutia \& Leonard, 2013). Karwati (2014) menyimpulkan e-learning sebagai proses instruksi atau pembelajaran yang melibatkan penggunaan peralatan elektronik dalam menciptakan, membantu perkembangan, menyampaikan, menilai dan memudahkan suatu proses belajar mengajar di mana pelajar sebagai pusatnya serta dilakukan secara interaktif kapanpun dan di manapun. Menurut Kusmana (2011) e-learning merupakan pembelajaran yang pelaksanaannya didukung oleh jasa teknologi, seperti telepon, audio, video, transmisi satelit atau komputer. Suartama (2014) mendefinisikan e-learning sebagai proses pembelajaran yang difasilitasi/memanfaatkan dukungan teknologi internet/ICT. Hal ini juga sejalan dengan yang disampaikan oleh Mutia \& Leonard (2013) yang menyimpulkan definisi e-learning sebagai sistem atau konsep pendidikan yang memanfaatkan ICT dalam proses belajar-mengajar.

Melalui e-learning, pengajar dapat mengelola materi pembelajaran, mulai dari menyusun silabi, mengupload materi, memberikan tugas, menerima dan menilai tugas, membuat tes/kuis, memonitor keaktifan, mengolah nilai dan juga berinteraksi dengan pelajar dan sesama pengajar melalui forum diskusi dan chat. Di sisi lain, pelajar juga dapat mengakses informasi dan materi pembelajaran, berinteraksi dengan pengajar dan sesama pelajar, melakukan transaksi tugas, mengerjakan tes/kuis, melihat pencapaian hasil belajar, dan lain-lain (I. K. Suartama, 2014). 
Sistem e-learning dapat diimplementasikan dalam bentuk asynchronous (pada waktu yang berbeda), synchronous (pada waktu yang sama) ataupun campuran antara keduanya (Mutia \& Leonard, 2013). Sistem ini memiliki 5 (lima) kategori yaitu:

1. learner-led e-learning, dimana e-learning dirancang untuk memungkinkan pelajar agar dapat belajar secara mandiri. Dalam learner-led learning, semua materi dikemas dan dikirim melalui jaringan internet atau web;

2. instructor-led e-learning, dimana internet atau web digunakan untuk menyampaikan pembelajaran seperti pada kelas konvensional. Bentuk synchronous banyak digunakan seperti konferensi video, audio, chatting, bulletin board, dan sejenisnya;

3. facilitated e-learning, yang merupakan kombinasi dari learner-led dan instructor-led elearning;

4. embedded e-learning, dimana upaya dilakukan agar terjadi semacam just-in time training dengan tujuan agar dapat memberikan bantuan segera pada seseorang yang ingin menguasai pengetahuan atau keterampilan sesegera mungkin saat itu juga dengan bantuan aplikasi program yang ditanam di website;

5. telementoring dan e-coaching, dimana teknologi internet dan web digunakan untuk memberikan bimbingan dan pelatihan jarak jauh, bisa melalui telekonferensi, chatting, instant messaging atau telepon.

Manfaat dan kelebihan e-learning diantaranya, yaitu (Adedoyin \& Soykan, 2020; Ainiyah, 2015; Alhabeeb \& Rowley, 2018; Chandrawati, 2010; Elyas, 2018; Karwati, 2014;

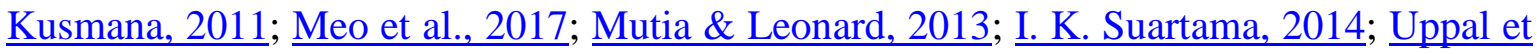
al., 2018):

1. Meningkatkan kualitas belajar melalui peningkatan interaksi pembelajaran;

Kemajuan belajar tergantung pada banyak faktor, diantaranya yaitu latar belakang dan lingkungan virtual dimana interaksi tersebut terjadi. Perilaku pelajar dan level kepercayaan dari pelajar juga memengaruhi kepuasan dan hasil belajar.

2. Standarisasi dan efektivitas pembelajaran dan mengubah budaya belajar-mengajar;

Salah satunya yaitu mempermudah penyempurnaan dan penyimpanan materi pembelajaran. Materi dan petunjuk pembelajaran terstruktur dan terjadwal melalui internet sehingga pelajar dan pengajar bisa saling menilai sampai seberapa jauh bahan ajar yang dipelajari. E-learning selalu memiliki kualitas yang sama setiap kali diakses dan tidak tergantung suasana hati pengajar. E-learning juga dirancang agar dapat 
memperbaiki tingkat pemahaman dan daya ingat pelajar dengan menggunakan konten yang bervariasi, interaksi yang menarik perhatian diantaranya melalui simulasi dan animasi. Pelajar juga dapat belajar, me-review atau mencari tambahan informasi yang berkaitan dengan bahan ajar setiap saat dan di mana saja kalau diperlukan. Pelajar dan pengajar juga dapat berkomunikasi secara mudah dan reguler, mendapatkan immediate feedback tanpa dibatasi jarak, tempat dan waktu. Selain itu, dengan adanya forum diskusi dan adanya kerjasama dalam komunitas online dapat menambah ilmu pengetahuan dan wawasan yang lebih luas. E-learning juga kompatibel dengan ilmu sosial dan humaniora, ilmu olahraga, teknik dan ilmu kedokteran.

3. Mengubah cara belajar pelajar yang pasif kepada budaya belajar aktif dan pelajar menjadi lebih bertanggung jawab atas kesuksesannya;

Budaya belajar aktif memungkinkan terjadinya independent learning dimana pelajar secara bebas/mandiri menentukan kapan akan dimulai, kapan akan menyelesaikan, bagian mana dari materi yang akan dipelajari terlebih dahulu atau bahkan melewatkan materi yang dianggap sudah dikuasai. Pelajar juga dapat menghubungi pengajar/instruktur/nara sumber melalui e-mail atau melalui dialog interaktif atau membaca hasil diskusi di message board.

4. Fleksibilitas, dalam hal waktu dan tempat dan kecepatan pembelajaran;

Hal ini membuat e-learning dapat menjangkau pelajar dalam cakupan yang luas, dapat memperluas basis dan kesempatan belajar oleh masyarakat karena memungkinkan terjadinya interaksi pembelajaran dari mana saja dan kapan saja. Fleksibilitas ini juga diperoleh dari kombinasi informasi tentang kepercayaan dan interaksi belajar yang nyaman.

5. Relatif lebih efisien, terutama terkait dengan biaya, baik finansial maupun non finansial seperti biaya transportasi, akomodasi, administrasi pengelolaan, penyediaan sarana dan prasarana, dan lain-lain;

Dengan menggunakan e-learning, pelajar dan pengajar dapat menghemat waktu dan uang untuk mencapai suatu tempat pembelajaran dan dapat diakses dari berbagai lokasi dan tempat. Administrasi dan pengelolaan yang terpusat akan memudahkan akses operasional. Jumlah pelajar juga tidak terbatas dengan kapasitas kelas; dan

6. Mengembangkan dan memperluas produk dan layanan baru.

Dengan meningkatkan kenyamanan bagi pelajar yang memiliki keterbatasan jarak dan waktu, maka e-learning menjadi solusi yang tepat. 
Walaupun metode e-learning memiliki banyak manfaat dan kelebihan, namun $e$ learning juga memiliki keterbatasan, antara lain: (1) Budaya, dimana banyak orang yang kurang berminat untuk belajar karena telah terbiasa dengan pola konvensional; (2) Investasi, dimana penyedia program e-learning harus mengeluarkan biaya tertentu sebagai pendukung sistem e-learning; (3) Teknologi dan infrastruktur, seperti kurangnya spesifikasi hardware komputer, browser yang tidak sinkron, penggunaan internet dengan kapasitas yang belum merata dan belum meratanya jangkauan internet di Indonesia; (4) Materi yang harus menggunakan fisik sulit dimasukkan dalam aplikasi e-learning seperti olahraga dan kesenian walaupun dalam sistem e-learning dapat dijelaskan konsepnya terlebih dahulu (Ainiyah, 2015; Mutia \& Leonard, 2013).

Keterbatasan ini juga ditambah dengan kekurangan e-learning antara lain harus memiliki komputer dan akses internet; harus memiliki kompetensi digital seperti keterampilan komputer dengan programnya; harus memiliki koneksi internet yang baik; pelajar mungkin akan berhenti belajar atau bingung mengenai kegiatan belajar dan tenggat waktu tugas; pelajar akan merasa sangat jauh dengan instruktur/pengajar; baik pengajar maupun pelajar harus memiliki kemampuan menulis dan berkomunikasi dengan baik agar tidak terjadi salah pengertian (Adedoyin \& Soykan, 2020; Chandrawati, 2010; Kusmana, 2011; Kusmiati \& Rahadi, 2020; Mutia \& Leonard, 2013).

Disamping itu, terdapat pula tantangan mengenai pembelajaran e-learning antara lain kurangnya interaksi antara pengajar dan pelajar bahkan antar pelajar itu sendiri. Hal ini bisa memperlambat terbentuknya values dalam proses belajar dan mengajar; mengurangi pengalaman dan mengurangi atmosfer belajar; adanya kecenderungan untuk mengabaikan aspek akademik atau aspek sosial dan sebaliknya mendorong tumbuhnya aspek bisnis/komersial; proses belajar mengajar cenderung ke arah pelatihan daripada pendidikan; berubahnya peran pengajar dari yang semula menguasai teknik pembelajaran konvensional, kini juga dituntut mengetahui teknik pembelajaran menggunakan ICT; pelajar yang tidak mempunyai disiplin dan motivasi belajar yang tinggi cenderung gagal; tidak semua tempat memiliki fasilitas internet; kurangnya tenaga yang mengetahui dan memiliki keterampilan internet; dan kurangnya penguasaan bahasa komputer (Chandrawati (2010); Elyas (2018); Kusmana (2011) dan Uppal et al., 2018)). 
Kesuksesan e-learning bisa dilihat dari sisi pengajar maupun pelajar. Faktor-faktor yang memengaruhinya bisa dibagi menjadi beberapa kategori seperti karakteristik pengajar, karakteristik pelajar, infrastuktur teknologi, sistem e-learning, sumber daya belajar online, pengalaman, keterikatan, dukungan teknis dan pelatihan yang tersedia (Alhabeeb \& Rowley, 2018). Lebih lanjut Alhabeeb \& Rowley (2018) mengungkapkan bahwa perspektif pengajar berbeda dengan perspektif pelajar yang diakibatkan dari perbedaan level pengalaman yang dimiliki antara pengajar dan pelajar. Dari perspektif pengajar, faktor kritis bagi kesuksesan e-learning yaitu karakteristik pelajar, sistem e-learning dan pengalaman dalam menggunakan e-learning sedangkan dari perspektif pelajar, faktor kritisnya yaitu infrastruktur teknologi, karakteristik pengajar dan karakteristik pelajar.

E-learning yang sukses tentu berkualitas. Berdasarkan penelitian yang dilakukan oleh Uppal et al. (2018), kualitas pelayanan e-learning dipengaruhi secara signifikan oleh learning content (konten pembelajaran), responsiveness (responsif atau tanggap dalam pelayanan) dan tangibility (ketersediaan fasilitas fisik, SDM dan sarana komunikasi), sedangkan assurance (adanya kepastian dan kepercayaan), empathy (perhatian yang diberikan) dan realibiity (keandalan) tidak memengaruhi kualitas pelayanan. Oleh karenanya, implementasi e-learning harus memperhatikan konten e-learning, ketersediaan sarana dan prasarana, personil, sarana komunikasi untuk merespon pelajar secara cepat dan tepat tanpa mengabaikan assurance, empathy dan reliabiity. E-learning yang berkualitas dapat dilihat dari tingkat kepuasan pelajar yang akan berdampak pada peningkatan kompetensi.

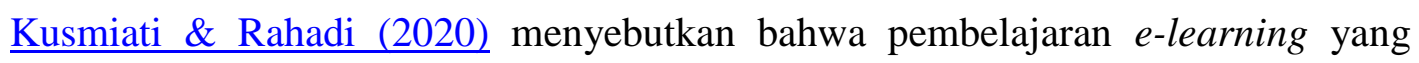
mendukung pengembangan kompetensi harus memiliki kondisi sebagai berikut:

1. Adanya manajemen kelas yang efektif, memaksimalkan efisiensi, memelihara disiplin dan moral, mempromosikan kerja tim, perencanaan, komunikasi, fokus pada hasil, mengevaluasi kemajuan dan membuat penyesuaian secara konstan. Berbagai strategi harus digunakan untuk mempromosikan hubungan yang positif, kerjasama dan tujuan belajar. Mengorganisir, menugaskan dan mengatur waktu, ruang dan kegiatan harus memastikan keterlibatan pelajar yang aktif dan adil dalam tugas-tugas yang produktif;

2. Adanya praktik pengajaran yang efektif. Berbagai strategi pengajaran harus melibatkan pelajar dan memberikan kesempatan belajar aktif yang mendorong perkembangan pemahaman yang dalam, pemecahan masalah dan meningkatkan kinerja belajar;

3. Adanya penilaian yang efektif dengan menggabungkan tes formal, kuis, evaluasi tugas kelas, kinerja dan proyek, tes prestasi standar. Strategi penilaian juga harus 
dikembangkan dengan melibatkan pelajar dalam menilai diri sendiri untuk membantu mereka menyadari kekuatan dan kebutuhan mereka serta mendorong mereka untuk menetapkan tujuan pribadi;

4. Memiliki keterampilan teknologi dan menentukan jenis dan tingkat teknologi yang paling sesuai dalam memaksimalkan proses pembelajaran.

Suartama (2014) juga menyebutkan bahwa selanjutnya dikenal pula istilah blended learning (hybrid learning) yakni pembelajaran yang menggabungkan semua bentuk pembelajaran seperti on-line, live maupun tatap muka.

\section{Latsar CPNS sebagai salah satu bentuk Pengembangan Kompetensi}

Menurut Lembaga Administrasi Negara (2018), Latsar CPNS adalah pelatihan yang dilaksanakan dalam masa prajabatan CPNS. Masa prajabatan ini merupakan masa percobaan yang harus dijalani oleh CPNS selama satu tahun terhitung sejak tanggal pengangkatan sebagai CPNS. Latsar CPNS bertujuan untuk mengembangkan kompetensi CPNS. Latsar CPNS dilakukan secara terintegrasi untuk membangun integritas moral, kejujuran, semangat dan motivasi nasionalisme dan kebangsaan, karakter kepribadian yang unggul dan bertanggung jawab, dan memperkuat profesionalisme serta kompetensi bidang. Latsar CPNS pada hakikatnya merupakan proses pengembangan kompetensi pegawai sebelum resmi diangkat menjadi seorang PNS.

Lembaga Administrasi Negara (2018) menyebutkan tiga jenis kompetensi yang dibangun dalam Latsar CPNS, yaitu kompetensi sosial kultural, kompetensi teknis administratif, serta kompetensi teknis substantif. Kompetensi sosial kultural merupakan pengetahuan, keterampilan, dan sikap/perilaku yang dapat diamati, diukur, dan dikembangkan terkait dengan pengalaman berinteraksi dengan masyarakat majemuk dalam hal agama, suku dan budaya, perilaku, wawasan kebangsaan, etika, nilai-nilai, moral, emosi dan prinsip yang harus dipenuhi oleh setiap CPNS untuk memperoleh hasil kerja sesuai dengan peran, fungsi dan jabatan. Kompetensi Teknis Administratif adalah pengetahuan, keterampilan, dan sikap/perilaku yang bersifat umum/administratif yang dapat diamati, diukur dan dikembangkan untuk mendukung pelaksanaan tugas. Kompetensi Teknis Substantif merupakan pengetahuan, keterampilan, dan sikap/perilaku yang bersifat teknis/substantif yang dapat diamati, diukur dan dikembangkan untuk mendukung pelaksanaan tugas, memfasilitasi pada pembentukan jabatan fungsional tertentu. 
Adapun kompetensi yang dibangun dalam Latsar CPNS dapat diukur berdasarkan empat kemampuan, yaitu menunjukkan sikap bela negara, mampu mengaktualisasikan nilainilai dasar PNS dalam pelaksanaan tugas jabatannya, mampu mengaktualisasikan kedudukan dan peran PNS dalam kerangka Negara Kesatuan Republik Indonesia, serta menunjukkan penguasaan kompetensi teknis yang dibutuhkan sesuai dengan bidang tugasnya. Untuk mengukur pengembangan kompetensi ini, maka dilakukan evaluasi peserta pelatihan.

Latsar CPNS diselenggarakan selama 51 (lima puluh satu) hari pelatihan yang setara dengan 511 (lima ratus sebelas) jam pelatihan (jp) dengan rincian selama 21 hari kerja dilaksanakan di instansi penyelenggara pelatihan (on campus) dan 30 hari kerja dilaksanakan di instansi asal peserta (off campus) dengan kurikulum yang telah ditetapkan, sebagai berikut:

Tabel 1. Kurikulum Latsar CPNS

\begin{tabular}{|c|c|c|c|}
\hline No & Mata Pelatihan & Tatap muka & $e$-learning \\
\hline 1 & $\begin{array}{l}\text { Kebijakan Pengembangan SDM Aparatur dan } \\
\text { Nilai-nilai ASN }\end{array}$ & $2 \mathrm{jp}$ & - \\
\hline 2 & Overview Kebijaka Penyelenggaraan Pelatihan & $4 \mathrm{jp}$ & - \\
\hline 3 & Dinamika Kelompok & $6 \mathrm{jp}$ & - \\
\hline 4 & Muatan Teknis Substantif Lembaga (MTSL) & $6 \mathrm{jp}$ & - \\
\hline \multirow[t]{2}{*}{5} & Konsepsi Aktualisasi & $3 \mathrm{jp}$ & - \\
\hline & \multicolumn{3}{|l|}{ Agenda I: Sikap Perilaku Bela Negara } \\
\hline 7 & $\begin{array}{l}\text { Wawasan Kebangsaan dan Nilai-nilai Bela } \\
\text { Negara }\end{array}$ & $6 \mathrm{jp}$ & - \\
\hline 8 & Analisis Isu Kontemporer & $9 \mathrm{jp}$ & - \\
\hline \multirow[t]{2}{*}{9} & Kesiapsiagaan Bela Negara & $30 \mathrm{jp}$ & - \\
\hline & \multicolumn{3}{|l|}{ Agenda II: Nilai-nilai Dasar PNS } \\
\hline 10 & Akuntabilitas PNS & $9 \mathrm{jp}$ & $3 \mathrm{jp}$ \\
\hline 11 & Nasionalisme & $9 \mathrm{jp}$ & $3 \mathrm{jp}$ \\
\hline 12 & Etika Publik & $9 \mathrm{jp}$ & $3 \mathrm{jp}$ \\
\hline 13 & Komitmen Mutu & 9 jp & $3 \mathrm{jp}$ \\
\hline \multirow[t]{2}{*}{14} & Anti Korupsi & $9 \mathrm{jp}$ & $3 \mathrm{jp}$ \\
\hline & \multicolumn{3}{|l|}{$\begin{array}{l}\text { Agenda III: Kedudukan dan Peran PNS } \\
\text { dalam NKRI }\end{array}$} \\
\hline
\end{tabular}




\begin{tabular}{|l|l|l|l|}
\hline 15 & Manajemen ASN & $6 \mathrm{jp}$ & - \\
\hline 16 & Whole of Government & $6 \mathrm{jp}$ & - \\
\hline 17 & Pelayanan Publik & $6 \mathrm{jp}$ & - \\
\hline 18 & Evaluasi Akademik & $5 \mathrm{jp}$ & - \\
\hline & Agenda IV: Habituasi & $6 \mathrm{jp}$ & - \\
\hline 19 & Penjelasan Aktualisasi & $9 \mathrm{jp}$ & - \\
\hline 20 & Pembimbinngan Rancangan Aktualisasi & $10 \mathrm{jp}$ & - \\
\hline 21 & Evaluasi Rancangan Aktualisasi & $2 \mathrm{jp}$ & - \\
\hline 22 & $\begin{array}{l}\text { Pembimbingan Pra Evaluasi Aktualisasi (di } \\
\text { instansi asal peserta) }\end{array}$ & & \\
\hline 23 & Evaluasi Aktualisasi & $10 \mathrm{jp}$ & - \\
\hline 24 & Pembekalan Habituasi & $3 \mathrm{jp}$ & \\
\hline 25 & Review Kebijakan Penyelenggaraan Pelatihan & $2 \mathrm{jp}$ & \\
\hline
\end{tabular}

Sumber: Lembaga Administrasi Negara (2018)

Selain struktur kurikulum Latsar CPNS yang dibagi menjadi 4 (empat) agenda besar tersebut, terdapat pula struktur kurikulum penguatan teknis bidang tugas yang semuanya bertujuan untuk mengembangkan kompetensi peserta pelatihan. Struktur kurikulum penguatan teknis bidang tugas menekankan pada praktik pengembangan kompetensi yang mendukung pelaksanaan tugas dan jabatan peserta. Strukur ini terdiri atas agenda untuk memenuhi kompetensi teknis administratif dan agenda untuk memenuhi kompetensi teknis substantif. Kurikulum ini dilaksanakan pada saat peserta berada di tempat kerjanya masingmasing (off campus).

Untuk mengukurnya, maka dilaksanakan evaluasi peserta. Evaluasi peserta Latsar CPNS terdiri atas evaluasi sikap perilaku, evaluasi akademik, dan evaluasi aktualisasi, serta evaluasi penguatan kompetensi teknis bidang tugas. Adapun kualifikasi penilaian evaluasi peserta Latsar CPNS ditetapkan mengikuti ketentuan sebagai berikut:

1. Sangat memuaskan (skor 90,01 - 100);

2. Memuaskan (skor $80,01-90,0$ );

3. Cukup memuaskan (skor 70,01-80,0);

4. Kurang memuaskan (skor $60,01-70,0$ ); dan

5. Tidak memuaskan $($ skor $\leq 60)$. 
Evaluasi sikap perilaku dilakukan setelah peserta menyelesaikan pembelajaran pada agenda I (agenda sikap perilaku bela negara). Nilai evaluasi sikap dan perilaku diberikan oleh lembaga penyelenggara pelatihan dan instansi asal peserta. Lembaga pelatihan menilai sikap dan perilaku peserta melalui penilaian dari pengajar (pengampu materi, penguji, coach dan mentor), pengelola dan penyelenggara pelatihan serta pendamping peserta. Pendamping peserta merupakan tenaga pelatihan yang bertugas mendampingi peserta dalam menanamkan nilai-nilai kedisiplinan, sikap perilaku, kebersamaan degan fokus pada penguatan fisik/jasmani, rohani dan spiritual selama pelatihan.

Evaluasi akademik dilakukan setelah seluruh mata pelatihan pada agenda II dan agenda III (agenda nilai-nilai dasar PNS dan agenda peran dan kedudukan PNS dalam NKRI) selesai diberikan. Nilai evaluasi akademik menunjukkan pemahaman peserta pada mata pelatihan agenda II dan agenda III ini.

Evaluasi aktualisasi merupakan penilaian terhadap peserta dalam proses pembelajaran aktualisasi di tempat kerja. Dalam evaluasi ini, peserta dinilai dalam hal kualitas isu yang diangkat dan dampaknya terhadap organisasi, banyaknya kegiatan yang relevan dalam mengatasi isu tersebut dan kaitannya dengan aktualisasi nilai-nilai dasar PNS. Teknik komunikasi peserta juga dinilai pada saat mempresentasikan aktualisasinya.

Evaluasi penguatan kompetensi teknis bidang tugas dilakukan setelah peserta menyelesaikan pembelajaran pada kurikulum penguatan kompetensi teknis bidang tugas. Evaluasi ini dilakukan oleh instansi asal peserta melalui unit pengelola SDM aparatur instansi.

\section{METODE PENELITIAN}

Pendekatan penelitian yang digunakan adalah pendekatan penelitian kuantitatif.

\section{Lokasi dan Waktu Penelitian}

Lokus penelitian ini yaitu Pusat Pelatihan dan Pengembangan dan Pemetaan Kompetensi Aparatur Sipil Negara Lembaga Administrasi Negara (Puslatbang PKASN LAN) yang berlokasi di Jl. Kiarapayung Km 4,7 Jatinangor, Sumedang.

Pemilihan lokus penelitian dilakukan dengan mempertimbangkan beberapa hal. Pertama, jumlah angkatan dalam penyelenggaraan kegiatan Pelatihan Dasar CPNS yang dilakukan oleh Puslatbang PKASN sebanyak 10 (sepuluh) angkatan pada tahun 2019, dan 6 
(enam) angkatan pada tahun 2020. Kedua, dalam pengelolaan kegiatan pelatihan dan pengembangan, Puslatbang PKASN LAN memiliki SDM, baik pengajar maupun penyelenggara, yang siap dalam menerapkan sistem e-learning yang akan dipergunakan pada penyelenggaraan pelatihan.

Puslatbang PKASN LAN juga telah dilengkapi dengan infrastuktur teknologi dan sistem e-learning yang mumpuni untuk membantu penyelenggaraan kegiatan pelatihan menjadi lebih optimal. Beberapa aspek tersebut menunjukkan bahwa pengelolaan kegiatan pelatihan di Puslatbang PKASN LAN, khususnya dalam penyelenggaraan kegiatan Latsar CPNS yang sifatnya tatap muka (klasikal) maupun non-klasikal telah merepresentasi topik kajian dimaksud. Adapun periode penelitian ini yaitu tahun 2019-2020.

\section{Populasi dan Sampel}

Populasi penelitian ini adalah seluruh peserta Latsar CPNS Golongan III yang mengikuti pelatihan di Puslatbang PKASN LAN pada periode 2019 - 2020. Periode Januari 2019 - Februari 2020 adalah periode sebelum Pandemi Covid-19, sementara periode Maret 2020 - Desember 2020 adalah periode Pandemi Covid-19.

Pada periode sebelum Pandemi Covid-19, kegiatan Latsar CPNS Golongan III berjumlah 12 angkatan dengan total peserta sebanyak 474 orang. Sementara periode Pandemi Covid-19, kegiatan Latsar CPNS untuk Golongan III berjumlah 4 angkatan dengan total peserta sebanyak 160 orang. Informasi mengenai kedua kelompok peserta Latsar CPNS tersebut disajikan pada Tabel 2 berikut ini.

Tabel 2.

Komposisi Peserta Latsar CPNS Sebelum dan Pada Saat Pandemi Covid-19

\begin{tabular}{|l|l|l|}
\hline \multirow{2}{*}{ Jenis Kelamin } & \multicolumn{2}{|l|}{ Peserta Latsar CPNS } \\
\cline { 2 - 3 } & Sebelum Pandemi & Saat Pandemi \\
\hline Pria & 191 & 58 \\
\hline Wanita & 283 & 102 \\
\hline Jumlah & 474 & 160 \\
\hline
\end{tabular}

Sumber: Puslatbang PKASN LAN 
Sampel yang digunakan pada penelitian ini adalah sampel jenuh, dimana jumlah sampel sama dengan jumlah populasi (Sugiyono, 2015).

\section{Teknik Pengumpulan Data}

Untuk mengetahui kompetensi peserta Latsar CPNS, baik sebelum Pandemi Covid19 maupun pada saat Pandemi Covid-19, data yang digunakan adalah data nilai hasil evaluasi peserta Latsar CPNS. Terdapat empat nilai evaluasi peserta Latsar CPNS, yaitu evaluasi sikap dan perilaku, evaluasi akademik, evaluasi aktualisasi, serta evaluasi kompetensi teknis bidang tugas. Keempat data tersebut merupakan data sekunder yang diperoleh dari database Puslatbang PKASN yang berskala ordinal.

\section{Teknik Analisis Data}

Setelah data diperoleh, kemudian data tersebut direkap, diolah dan dilakukan analisis data. Pada tahap pengolahan data, data diolah menggunakan program SPSS versi 23. Selanjutnya, dilakukan uji normalitas untuk melihat apakah data berdistribusi normal atau tidak. Apabila data berdistribusi normal, maka untuk mengetahui apakah terdapat perbedaan kompetensi peserta Latsar CPNS sebelum Pandemi Covid-19 dan pada saat Pandemi Covid19, dilakukan uji t. Namun apabila data yang digunakan tidak berdistribusi normal, maka untuk mengetahui apakah terdapat perbedaan kompetensi peserta Latsar CPNS sebelum Pandemi Covid-19 dan pada saat Pandemi Covid-19 selanjutnya dilakukan uji MannWhitney.

Dalam melakukan pengujian, kriteria yang digunakan untuk menolak atau menerima hipotesis adalah berdasarkan P-value yang diperoleh dari output program SPSS versi 23. Apabila $\mathrm{P}$ - value $<\alpha$, maka $\mathrm{H}_{0}$ ditolak, sementara apabila $\mathrm{P}$ - value $\geq \alpha$, maka $\mathrm{H}_{0}$ diterima. Adapun hipotesis yang akan diuji adalah sebagai berikut:

$\mathrm{H}_{0}$ : Kompetensi peserta Latsar CPNS sebelum Pandemi Covid -19 secara signifikan sama dengan kompetensi peserta Latsar CPNS pada saat Pandemi Covid -19.

$\mathrm{H}_{1}$ : Kompetensi peserta Latsar CPNS sebelum Pandemi Covid -19 secara signifikan berbeda dengan kompetensi peserta Latsar CPNS pada saat Pandemi Covid -19.

\section{HASIL DAN PEMBAHASAN}

Pelaksanaan Latsar CPNS dan Kompetensi Peserta Latsar CPNS Sebelum Masa Pandemi Covid-19 
Pada tahun 2019, sejak diterbitkannya Peraturan LAN No. 12 Tahun 2018 tentang Pelatihan Dasar Calon Pegawai Negeri Sipil, Latsar CPNS diselenggarakan secara tatap muka, dengan tambahan metode $e$-learning selama 3 jam pelatihan (jp) pada pembelajaran agenda II yaitu nilai-nilai dasar PNS (Akuntabilitas, Nasionalisme, Etika Publik, Komitmen Mutu dan Anti Korupsi). Learning Management System (LMS) yang digunakan oleh Puslatbang PKASN LAN untuk mengakses sistem e-learning tersebut yaitu melalui laman diklat.bandung.lan.go.id/elearning.

Kompetensi peserta Latsar CPNS sebelum Pandemi Covid-19 dilihat berdasarkan nilai evaluasi akademik, nilai aktualisasi, nilai sikap dan perilaku, serta nilai kompetensi teknis bidang tugas yang ditunjukkan pada tabel berikut:

Tabel 3.

Nilai Evaluasi Peserta Latsar CPNS Sebelum Pandemi Covid-19

\begin{tabular}{|l|l|l|l|l|}
\hline & Akademik & Aktualisasi & Sikap dan Perilaku & $\begin{array}{l}\text { PKT } \\
\text { BT }\end{array}$ \\
\hline Min & 70,01 & 70,01 & 75,19 & 75,01 \\
\hline Max & 92,08 & 99,20 & 98,40 & 100 \\
\hline Mean & 80,75 & 87,02 & 80,37 & 87,72 \\
\hline Stdev & 4,22 & 3,82 & 3,12 & 4,87 \\
\hline
\end{tabular}

Sumber: Diolah, 2021

Berdasarkan tabel 3, dapat diketahui bahwa keempat nilai evaluasi peserta Latsar CPNS berada pada kategori cukup memuaskan hingga sangat memuaskan. Hal ini dapat dilihat berdasarkan nilai minimum dan maksimum dari setiap nilai evaluasi. Sementara apabila dilihat dari rata-ratanya, nilai evaluasi peserta Latsar CPNS sebelum Pandemi Covid19 berada pada kategori memuaskan. Hal ini dapat dilihat berdasarkan nilai mean yang berada pada rentang 80,01 hingga 90,00 .

\section{Pelaksanaan Latsar CPNS dan Kompetensi Peserta Latsar CPNS Pada Masa Pandemi Covid-19}

Metode pembelajaran Latsar CPNS mengalami perubahan drastis sejak masa Pandemi Covid-19 sesuai dengan SE Kepala LAN No. 10/K.1/HKM.02.3/2020 tanggal 23 Maret 2020 Tentang Panduan Teknis Penyelenggaraan Pelatihan dalam Masa Pandemi 
Covid-19. Pada masa Pandemi Covid-19, metode e-learning pada penyelenggaraan Latsar CPNS menjadi lebih banyak dibandingkan dengan tatap muka. Pembelajaran tatap muka hanya dilakukan selama 3 (tiga) hari pada tahap akhir pelatihan yaitu pada agenda pembelajaran bela negara, ditambah dengan seminar aktualisasi dan penutupan.

Salah satu penyesuaian yang dilakukan yaitu pada proses pembelajaran, di mana semula dilakukan secara tatap muka menjadi non-tatap muka dengan metode distance learning. Metode ini dilakukan dengan memanfaatkan LMS yang biasa digunakan sebelumnya ditambah dengan video conference melalui aplikasi zoom cloud meetings.

Jumlah peserta Latsar CPNS Golongan III pada masa Pandemi Covid-19 adalah sebanyak 160 orang yang terdiri dari 58 orang laki-laki, dan 102 orang perempuan. Kompetensi peserta Latsar CPNS pada masa Pandemi Covid-19 yang dilihat berdasarkan nilai evaluasi akademik, nilai aktualisasi, nilai sikap dan perilaku, serta nilai kompetensi teknis bidang tugas ditunjukkan pada Tabel 4 berikut ini:

Tabel 4. Nilai Evaluasi Peserta Latsar CPNS pada Masa Pandemi Covid19

\begin{tabular}{|c|c|c|c|c|}
\hline & Akademik & Aktualisasi & Sikap dan Perilaku & PKT BT \\
\hline Min & 70,40 & 70,01 & 83,86 & 72,17 \\
\hline Max & 91,40 & 95,26 & 86,86 & 98,13 \\
\hline Mean & 82,67 & 88,76 & 85,51 & 87,74 \\
\hline Stdev & 4,45 & 2,83 & 0,51 & 5,22 \\
\hline
\end{tabular}

Sumber: diolah, 2021

Berdasarkan tabel 4 tersebut dapat diketahui bahwa keempat nilai evaluasi peserta Latsar CPNS pada masa Pandemi Covid-19 berada pada kategori cukup memuaskan hingga sangat memuaskan. Hal ini dapat dilihat berdasarkan nilai minimum dan maksimum dari setiap nilai evaluasi. Sementara apabila dilihat dari rata-ratanya, nilai evaluasi peserta Latsar CPNS pada masa pandemi Covid-19 berada pada kategori memuaskan. Hal ini dapat dilihat berdasarkan nilai mean yang berada pada rentang 80,01 hingga 90,00.

\section{Perbandingan Kompetensi Peserta Latsar CPNS Sebelum dan Pada Masa Pandemi Covid-19}


Kegiatan Latsar CPNS dilakukan untuk membangun tiga kompetensi, yaitu kompetensi sosial kultural, kompetensi teknis administratif, dan kompetensi teknis substantif. Kompetensi yang dibangun dalam Latsar CPNS dapat diukur berdasarkan empat kemampuan, yaitu menunjukkan sikap bela negara, mampu mengaktualisasikan nilai-nilai dasar PNS dalam pelaksanaan tugas jabatannya, mampu mengaktualisasikan kedudukan dan peran PNS dalam kerangka Negara Kesatuan Republik Indonesia, serta menunjukkan penguasaan kompetensi teknis yang dibutuhkan sesuai dengan bidang tugasnya. Keempat kemampuan tersebut terejawantahkan ke dalam nilai evaluasi akademik, evaluasi aktualisasi, evaluasi sikap dan perilaku, serta evaluasi kompetensi teknis bidang.

Berdasarkan nilai evaluasi peserta Latsar CPNS sebelum dan pada masa Pandemi Covid-19, dapat dilihat bahwa rata-rata kompetensi menunjukkan kategori yang sama. Nilai evaluasi peserta Latsar CPNS sebelum dan pada masa Pandemi Covid-19 tersebut berada pada kategori cukup memuaskan hingga sangat memuaskan. Begitu pula apabila dilihat berdasarkan nilai rata-rata kedua kelompok tersebut yang menunjukkan kategori memuaskan. Tabel 5 berikut ini menunjukkan perbandingan nilai evaluasi peserta Latsar CPNS sebelum dan pada saat pandemi Covid-19.

\section{Tabel 5.}

Perbandingan Nilai Evaluasi Peserta Latsar CPNS Sebelum dan Pada Saat Pandemi Covid-19

\begin{tabular}{lll}
\hline Statistik Deskriptif & Sebelum Pandemi & Pada Saat Pandemi \\
\hline Evaluasi Akademik & Mean $=80,75$ & Mean $=82,67$ \\
& Stdev $=4,22$ & Stdev $=4,45$ \\
& Min $=70,01$ & Min $=70,40$ \\
& Max $=92,08$ & Max $=91,40$ \\
\hline Evaluasi Aktualisasi & Mean $=87,02$ & Mean $=88,76$ \\
& Stdev $=3,82$ & Stdev $=2,83$ \\
& Min $=70,01$ & Min $=70,01$ \\
Evaluasi Sikap dan & Mean $=89,37$ & Max $=95,26$ \\
Perilaku & Stdev $=3,12$ & Stdev $=0,51$ \\
& Min $=75,19$ & Min $=83,86$ \\
& Max $=98,40$ & Max $=86,86$
\end{tabular}




\begin{tabular}{lll}
\hline Evaluasi Kompetensi & Mean $=87,72$ & Mean $=87,74$ \\
Teknis Bidang & Stdev $=4,87$ & Stdev $=5,22$ \\
& Min $=75,01$ & Min $=72,17$ \\
& Max $=100,00$ & Max $=98,13$ \\
\hline
\end{tabular}

Sumber: diolah, 2021

Berdasarkan tabel 5, dapat diketahui bahwa nilai statistik deskriptif (mean, standar deviasi, minimum, dan maksimum) untuk nilai evaluasi akademik, evaluasi aktualisasi, evaluasi sikap dan perilaku, serta evaluasi kompetensi teknis bidang memiliki nilai yang tidak terpaut jauh antara sebelum terjadi Pandemi Covid-19 dengan pada saat Pandemi Covid-19. Secara kasat mata, hal ini menunjukkan bahwa tidak terdapat perbedaan kompetensi peserta Latsar CPNS sebelum dan pada saat Pandemi Covid-19. Namun, untuk mengetahui lebih jauh apakah secara signifikan tidak terdapat perbedaan kompetensi peserta Latsar CPNS sebelum dan pada saat Pandemi Covid-19 harus dilakukan melalui pengujian hipotesis.

\section{Uji Normalitas}

Sebelum dilakukan pengujian hipotesis, terlebih dahulu dilakukan uji normalitas terhadap hasil evaluasi peserta Latsar CPNS. Hasil uji normalitas terhadap keempat nilai evaluasi peserta Latsar CPNS dapat dilihat pada Tabel 6 berikut:

Tabel 6. Hasil Uji Normalitas Nilai Evaluasi Peserta Latsar CPNS

Sebelum dan Pada Masa pandemi Covid19

\begin{tabular}{|c|c|c|c|c|c|c|c|}
\hline \multirow{3}{*}{\multicolumn{2}{|c|}{ Kelompok }} & \multicolumn{6}{|c|}{ Tests of Normality } \\
\hline & & \multicolumn{3}{|c|}{ Kolmogorov-Smirnov ${ }^{a}$} & \multicolumn{3}{|c|}{ Shapiro-Wilk } \\
\hline & & Statistic & df & Sig. & Statistic & df & Sig. \\
\hline \multirow[t]{2}{*}{ Evaluasi_Akademik } & Sebelum Pandemi & .028 & 474 & $200^{\circ}$ & .993 & 474 & .025 \\
\hline & Pandemi & .057 & 160 & $.200^{\circ}$ & .985 & 160 & .081 \\
\hline \multirow[t]{2}{*}{ Evaluasi_Aktualisasi } & Sebelum Pandemi & .065 & 474 & .000 & .983 & 474 & .000 \\
\hline & Pandemi & .064 & 160 & $200^{\circ}$ & .892 & 160 & .000 \\
\hline \multirow[t]{2}{*}{ Evaluasi_Sikap_Perilaku } & Sebelum Pandemi & .215 & 474 & .000 & .793 & 474 & .000 \\
\hline & Pandemi & .112 & 160 & .000 & .975 & 160 & .005 \\
\hline \multirow{2}{*}{$\begin{array}{l}\text { Evaluasi_Kompetensi_T } \\
\text { eknis_Bidang }\end{array}$} & Sebelum Pandemi & .031 & 474 & $.200^{\circ}$ & .996 & 474 & .221 \\
\hline & Pandemi & .059 & 160 & $200^{\circ}$ & .986 & 160 & .102 \\
\hline
\end{tabular}


Sumber: diolah

Tabel 6 menunjukkan hasil uji normalitas terhadap nilai evaluasi peserta Latsar CPNS sebelum dan pada masa Pandemi Covid-19. Berdasarkan tabel tersebut dapat diketahui bahwa nilai evaluasi akademik dan nilai evaluasi kompetensi teknis bidang berasal dari populasi yang berdistribusi normal. Hal ini dapat terlihat dari nilai signifikansi Uji Kolmogorov-Smirnov maupun Shapiro-Wilk yang menunjukkan nilai di atas 0,05. Sementara nilai evaluasi aktualisasi dan nilai evaluasi sikap perilaku berasal dari populasi yang tidak berdistribusi normal. Hal ini dapat terlihat dari nilai signifikansi Uji KolmogorovSmirnov maupun Shapiro-Wilk yang menunjukkan nilai di bawah 0,05.

Selanjutnya, karena tidak semua nilai evaluasi berasal dari populasi yang berdistribusi normal, maka untuk membandingkan kompetensi peserta Latsar CPNS sebelum dan pada masa Pandemi Covid-19 dilakukan melalui uji Mann Whitney.

\section{Uji Mann - Whitney}

Uji Mann - Whitney dilakukan terhadap data yang memiliki skala ordinal dan berasal dari data yang sebagian atau seluruhnya tidak berdistribusi normal (Sugiyono, 2015). Uji ini dilakukan untuk menganalisis perbandingan kompetensi peserta Latsar CPNS sebelum dan pada masa Pandemi Covid-19. Berdasarkan hasil uji Mann - Whitney diperoleh hasil sebagai berikut:

Tabel 7. Hasil Uji Mann - Whitney Data Kompetensi Peserta Latsar CPNS Sebelum dan Pada Saat Pandemi Covid-19

\begin{tabular}{|l|r|r|r|r|}
\hline \multicolumn{1}{|c|}{ Test Statistics $^{\text {a }}$} \\
\hline & $\begin{array}{r}\text { Evaluasi_Aka } \\
\text { demik }\end{array}$ & $\begin{array}{c}\text { Evaluasi_Aktu } \\
\text { alisasi }\end{array}$ & $\begin{array}{r}\text { Evaluasi_Sik } \\
\text { ap_Perilaku }\end{array}$ & $\begin{array}{r}\text { Evaluasi_Ko } \\
\text { mpetensi_Te } \\
\text { knis_Bidang }\end{array}$ \\
\hline Mann-Whitney U & 28269.000 & 24932.000 & 6880.000 & 37712.500 \\
Wilcoxon W & 140844.000 & 137507.000 & 119455.000 & 50592.500 \\
Z & -4.818 & -6.483 & -15.501 & -.104 \\
Asymp. Sig. (2-tailed) & .000 & .000 & .000 & .917 \\
\hline
\end{tabular}


Sumber: diolah

Berdasarkan uji Mann-Whitney terhadap nilai evaluasi akademik peserta Latsar CPNS sebelum dan pada saat Pandemi Covid-19, menghasilkan nilai Z sebesar $-4,818$ dengan nilai P-value (Asymp. Sig (2-tailed)) sebesar 0,000. Karena nilai P-value ini lebih kecil dari taraf signifikansi $\alpha=0,05$ maka hipotesis yang menyatakan bahwa nilai evaluasi akademik peserta Latsar CPNS sebelum dan pada saat Pandemi Covid-19 sama secara signifikan ditolak. Hal ini berarti bahwa evaluasi akademik peserta Latsar CPNS sebelum dan pada saat Pandemi Covid-19 berbeda secara signifikan.

Berdasarkan uji Mann-Whitney terhadap nilai evaluasi aktualisasi peserta Latsar CPNS sebelum dan pada saat Pandemi Covid-19, menghasilkan nilai Z sebesar -6,483 dengan nilai P-value (Asymp. Sig (2-tailed)) sebesar 0,000. Karena nilai P-value ini lebih kecil dari taraf signifikansi $\alpha=0,05$ maka hipotesis yang menyatakan bahwa nilai evaluasi aktualisasi peserta Latsar CPNS sebelum dan pada saat Pandemi Covid-19 sama secara signifikan ditolak. Hal ini berarti bahwa evaluasi aktualisasi peserta Latsar CPNS sebelum dan pada saat Pandemi Covid-19 berbeda secara signifikan.

Berdasarkan uji Mann-Whitney terhadap nilai evaluasi sikap dan perilaku peserta Latsar CPNS sebelum dan pada saat Pandemi Covid-19, menghasilkan nilai Z sebesar 15,501 dengan nilai P-value (Asymp. Sig (2-tailed)) sebesar 0,000. Karena nilai P-value ini lebih kecil dari taraf signifikansi $\alpha=0,05$ maka hipotesis yang menyatakan bahwa nilai evaluasi sikap dan perilaku peserta Latsar CPNS sebelum dan pada saat Pandemi Covid-19 sama secara signifikan ditolak. Hal ini berarti bahwa evaluasi sikap dan perilaku peserta Latsar CPNS sebelum dan pada saat Pandemi Covid-19 berbeda secara signifikan.

Berdasarkan uji Mann-Whitney terhadap nilai evaluasi kompetensi bidang teknis peserta Latsar CPNS sebelum dan pada saat Pandemi Covid-19, menghasilkan nilai Z sebesar -0,104 dengan nilai P-value (Asymp. Sig (2-tailed)) sebesar 0,917. Karena nilai Pvalue ini lebih besar dari taraf signifikansi $\alpha=0,05$ maka hipotesis yang menyatakan bahwa nilai evaluasi akademik peserta Latsar CPNS sebelum dan pada saat Pandemi Covid-19 sama secara signifikan diterima. Hal ini menunjukkan bahwa evaluasi kompetensi bidang teknis peserta Latsar CPNS sebelum dan pada saat Pandemi Covid-19 sama secara signifikan.

Dari 4 (empat) nilai evaluasi, terdapat 3 (tiga) nilai yang berbeda secara signifikan, yaitu nilai evaluasi akademik, nilai evaluasi sikap dan perilaku serta nilai evaluasi aktualisasi. Ketiga nilai ini mewakili kompetensi peserta Latsar CPNS. Dapat disimpulkan bahwa 
kompetensi peserta Latsar CPNS sebelum dan pada saat Pandemi Covid-19 berbeda secara signifikan. Hal ini sejalan dengan hasil penelitian yang dilakukan oleh Kusmiati \& Rahadi $\underline{(2020)}$.

Perbedaan kompetensi antara peserta Latsar CPNS sebelum dan pada masa Pandemi Covid-19 terlihat dalam beberapa hal, yaitu sikap, perilaku, dan keterampilan yang dimiliki peserta Latsar CPNS. Misalnya, sebelum Pandemi Covid-19, setiap hari peserta Latsar CPNS melaksanakan apel pagi dalam rangka pembentukan karakter kedisiplinan peserta Latsar CPNS. Peserta Latsar CPNS yang terlambat apel pagi akan mendapatkan punishment. Hal ini tidak terjadi saat pembelajaran pada masa Pandemi Covid-19. Tidak ada lagi apel, dan ada saja peserta Latsar CPNS yang tidak tepat waktu memasuki ruang pembelajaran secara virtual. Positifnya, pembelajaran pada masa Pandemi Covid-19 memaksa peserta Latsar CPNS untuk bisa menggali informasi dan materi pembelajaran lebih mendalam, harus dapat berinteraksi dengan pengajar dan sesama peserta Latsar CPNS, dan melakukan berbagai kegiatan lainnya secara virtual.

Perbedaan kompetensi sebagaimana yang telah disebutkan terjadi salah satunya karena adanya perbedaan metode pembelajaran yang menjadi salah satu faktor adanya perbedaan kompetensi pada peserta pelatihan. Hal ini sejalan dengan apa yang diungkapkan oleh Munajatisari (2014), di mana sebelum adanya Pandemi Covid-19, penyelenggaraan Latsar CPNS dilaksanakan secara tatap muka langsung dimana para peserta diasramakan. Adapun e-learning dilaksanakan sebagai pelengkap pembelajaran. E-learning dilakukan pada malam hari selama 3 jp pada mata pelatihan agenda II (nilai-nilai dasar PNS). Metode pembelajaran secara tatap muka ini memungkinkan terjadinya interaksi secara langsung antara pengajar dan peserta seperti yang dikemukakan oleh Kiemer et al. (2018).

Namun pada masa pandemi Covid-19, porsi e-learning jauh lebih banyak di mana selama 16 (enam belas) hari, peserta harus mengikuti proses pembelajaran, berdiskusi, mendengarkan ceramah dan mengikuti evaluasi akademik melalui aplikasi video conference zoom cloud meetings yang seringkali mengalami kendala. Beberapa kendala yang dialami, baik oleh pengajar, penyelenggara maupun peserta diantaranya yaitu yaitu kendala jaringan internet yang tidak stabil, ketidaksepahaman antara pengajar dan peserta, kurangnya rasa kebersamaan dan kurangnya penguasaan teknologi pembelajaran. Hal ini sejalan dengan yang dikemukakan oleh Adedoyin \& Soykan (2020); Chandrawati (2010); Kusmana (2011); Kusmiati \& Rahadi (2020); dan Mutia \& Leonard (2013). 
Untuk mendukung pengembangan kompetensi peserta Latsar CPNS pada masa Pandemi Covid-19, proses pembelajaran pada metode e-learning harus memiliki beberapa kondisi. Kusmiati \& Rahadi (2020) menyebutkan setidaknya terdapat empat kondisi untuk mencapai tujuan tersebut. Pertama, adanya manajemen kelas yang efektif, memaksimalkan efisiensi, memelihara disiplin dan moral, mempromosikan kerja tim, perencanaan, komunikasi, fokus pada hasil, mengevaluasi kemajuan dan membuat penyesuaian secara konstan. Fasilitator dalam hal ini adalah widyaiswara memiliki peran yang sangat strategis dalam mempromosikan hubungan yang positif antara widyaiswara dengan peserta, peserta dengan peserta, ataupun antara peserta dengan penyelenggara pelatihan. Fasilitator harus mampu mengorganisir, memberi tugas dan mengatur waktu, dan memastikan adanya keterlibatan aktif dari peserta Latsar CPNS selama proses pembelajaran.

Kedua, adanya praktik pengajaran yang efektif. Berbagai strategi pengajaran harus melibatkan peserta dan memberikan kesempatan belajar aktif yang mendorong perkembangan pemahaman yang dalam, pemecahan masalah dan meningkatkan kinerja belajar. Ketiga, adanya penilaian yang efektif dengan menggabungkan tes formal, kuis, evaluasi tugas kelas, kinerja dan proyek, tes prestasi standar. Strategi penilaian juga harus dikembangkan dengan melibatkan peserta dalam menilai diri sendiri untuk membantu mereka menyadari kekuatan dan kebutuhan mereka serta mendorong mereka untuk menetapkan tujuan pribadi. Keempat, memiliki keterampilan teknologi dan menentukan jenis dan tingkat teknologi yang paling sesuai dalam memaksimalkan proses pembelajaran.

\section{PENUTUP}

\section{Kesimpulan}

Berdasarkan hasil analisis data dan pembahasan penelitian, dapat disimpulkan beberapa hal sebagai berikut. Pertama, kompetensi peserta Latsar CPNS sebelum Pandemi Covid-19 yang dilihat berdasarkan nilai evaluasi berada pada kategori cukup memuaskan hingga sangat memuaskan. Hal ini dapat dilihat berdasarkan nilai minimum dan maksimum dari setiap nilai evaluasi. Sementara apabila dilihat dari rata-ratanya, nilai evaluasi peserta Latsar CPNS sebelum Pandemi Covid-19 berada pada kategori memuaskan. Hal ini dapat dilihat berdasarkan nilai mean yang berada pada rentang 80,01 hingga 90,00.

Kedua, kompetensi peserta Latsar CPNS pada masa Pandemi Covid-19 berada pula pada kategori cukup memuaskan hingga sangat memuaskan. Hal ini dapat dilihat berdasarkan nilai minimum dan maksimum dari setiap nilai evaluasi. Sementara apabila dilihat dari rata- 
ratanya, nilai evaluasi peserta Latsar CPNS pada masa Pandemi Covid-19 berada pada kategori memuaskan. Hal ini dapat dilihat berdasarkan nilai mean yang berada pada rentang 80,01 hingga 90,00 .

Ketiga, berdasarkan empat nilai evaluasi peserta Latsar CPNS, tiga nilai evaluasi menunjukkan adanya perbedaan secara signifikan antara peserta Latsar CPNS sebelum dan pada masa Pandemi Covid-19. Tiga nilai evaluasi tersebut yaitu evaluasi akademik, evaluasi aktualisasi, serta evaluasi sikap dan perilaku. Sementara satu nilai evaluasi lainnya yaitu evaluasi kompetensi teknis bidang tugas memiliki kesamaan secara signifikan. Hal ini menunjukkan adanya perbedaan yang signifikan antara kompetensi yang dimiliki oleh peserta Latsar CPNS sebelum dan pada masa Pandemi Covid-19.

Perbedaan ini dapat disebabkan oleh penyesuaian metode pembelajaran yang semula dilaksanakan secara tatap muka menjadi blended-learning yang mungkin mengakibatkan culture shock baik bagi pengajar maupun bagi peserta pelatihan. Selain itu, beberapa kendala seperti jaringan internet yang tidak stabil, ketidaksepahaman antara pengajar dan peserta, kurangnya rasa kebersamaan dan kurangnya penguasaan teknologi pembelajaran juga dapat menjadi penyebab perbedaan kompetensi ini.

\section{Saran}

Kompetensi pegawai harus selalu dikembangkan agar kinerja individu meningkat dan akhirnya kinerja organisasi juga meningkat. Salah satu cara mengembangkan kompetensi pegawai yaitu dengan melaksanakan pendidikan dan pelatihan (pelatihan). Sejalan dengan perkembangan teknologi, penyelenggaraan pelatihan dengan metode $e$-learning merupakan keniscayaan yang harus dilakukan. Penyelenggara pelatihan harus mempersiapkan berbagai aspek terkait metode e-learning ini, diantaranya yaitu menyiapkan SDM terkait, seperti pengajar, pengelola dan tim penyelenggara, serta sarana dan prasarana pelatihan yang mendukung kesuksesan e-learning. Begitupun dengan peserta pelatihan yang harus mampu mengikuti arahan dan sistem pembelajaran yang dijalankan oleh instansi penyelenggara pelatihan. Semua ini tentunya untuk mencapai tujuan pelatihan.

Ruang lingkup penelitian ini adalah membahas secara deskriptif kuantitatif mengenai kompetensi peserta pelatihan, khususnya peserta Latsar CPNS, sebelum dan pada masa Pandemi Covid-19, namun belum membahas lebih dalam mengenai faktor-faktor yang menyebabkan terjadinya perbedaan kompetensi tersebut. Untuk itu, penelitian lanjutan yang 
dapat dilakukan adalah mengenai faktor-faktor yang menyebabkan terjadinya perbedaan kompetensi antara peserta pelatihan sebelum dan pada masa Pandemi Covid-19. 


\section{DAFTAR PUSTAKA}

Abdussamad, Y. (2017). Pengembangan Sumber Daya Manusia Aparatur Melalui Kompetensi. In Jurnal Ekonomi dan Bisnis Universitas Negeri Gorontalo.

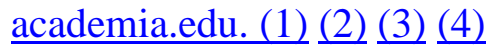

Adedoyin, O. B., \& Soykan, E. (2020). Covid-19 pandemic and online learning: the challenges and opportunities. Interactive Learning Environments, O(0), 1-13. https://doi.org/10.1080/10494820.2020.1813180 (1) (2) (3)

Ainiyah, Z. (2015). Penggunaan Edmodo sebagai Media Pembelajaran e-learning pada Mata Pelajaran Otomatisasi Perkantoran di SMKN 1 Surabaya. Jurnall Pendidikan Administrasi Perkantoran, 3(3), 10-17. (1) (2)

Alhabeeb, A., \& Rowley, J. (2018). E-learning Success Factors: Comparing Perspectives from Academic Staff and Students. Computers and Education, 127, 1-12. https://doi.org/10.1016/j.compedu.2018.08.007 (1) (2) (3)

Anwaruddin, A. (2006). Analisis Kebijakan Pengembangan Kompetensi Pegawai di Indonesia. Jurnal Wacana Kinerja, 9(2). (1) (2) (3)

Chandrawati, S. R. (2010). Pemanfaatan e-learning dalam Pembelajaran. Jurnal Cakrawala Kependidikan, 8(2), 172-181. (2) $\underline{\text { (3) }}$

Day, C. (2017). Competence-based Education and Teacher professional development. In Technical and Vocational Education and Training: Isues, Concerns and Prospects (Vol. 23, pp. 165-182). Springer Nature. https://doi.org/10.1007/978-3-319-41713-4_8 $\underline{(2)}$

Divayana, D. G. H. (2017). Evaluasi Pemanfaatan E-Learning di Universitas Teknologi Indonesia Menggunakan Model CSE-UCLA. Jurnal Cakrawala Pendidikan, 36(2), 280-289. https://doi.org/10.21831/cp.v36i2.12853

Efendi, N. (2015). Pengembangan Sumber Daya Manusia Berbasis Kompetensi di Kantor Pemerintah Kota Bandar Lampung. MIMBAR: Jurnal Sosial Dan Pembangunan, 31(1), $\underline{1-10 .}(2) \underline{(3)}$

Elyas, A. H. (2018). Penggunaan Model Pembelajaran E-Learning Dalam Meningkatkan Kualitas Pembelajaran. Jurnal Warta, 56(04), 1-11. (2)

Erni, S., Vebrianto, R., Miski, C. R., MZ, Z. A., Martius, \& Thahir, M. (2020). Refleksi Proses Pembelajaran Guru MTs dimasa Pendemi Covid 19 di Pekanbaru : Dampak dan Solusi. Journal of Education and Learning, 1(1), 1-10. 
Faisal, M., Burhanuddin, \& Ibrahim, S. (2020). Analisis Pengembangan Kompetensi Pegawai pada Dinas Pendidikan di Kota Makassar. Jurnal Pallangga Praja (JPP .... $\underline{1(2), 79-93 .} \underline{(2)} \underline{(3)}$

Fathurrochman, I. (2017). Pengembangan Kompetensi Pegawai Aparatur Sipil Negara (ASN) Sekolah Tinggi Agama Islam Negeri (STAIN) Curup Melalui Metode Pendidikan Dan Pelatihan. Manajer Pendidikan, 11(21), 120-129. https://ejournal.unib.ac.id/index.php/manajerpendidikan/article/viewFile/3210/1654 $\underline{(2)}$

Gardiner, S., \& Riecmann, M. (2015). Pedagogies of Preparedness: Use of Reflective Journals in the Operationalisation and Development of Anticipatory Competence. Sustainability, 7(8), 10554-10575. https://doi.org/10.3390/su70810554 (2)

Hartanto, W. (2016). Penggunaan E-Learning sebagai Media Pembelajaran. Jurnal Pendidikan Ekonomi, 10(1), 1-18.

Hassan, E. M., \& Varshosaz, K. (2016). The Assessment of the Efficiency of Classical and co-Operative Training in Promoting The Participation of Employees of R. PC in the Field of HSE. European Journal of Sustainable Development, 5(4), 151-166. https://doi.org/10.14207/ejsd.2016.v5n4p151

Karwati, E. (2014). Pengaruh Pembelajaran Elektronik (E-Learning) terhadap Mutu Belajar Mahasiswa. Jurnal Penelitian Komunikasi, 17(1), 41-54. https://doi.org/10.20422/jpk.v17i1.5 (2) (3) (4)

$\underline{\text { Kiemer, K., Groschner, A., Kunter, M., \& Seidel, T. (2018). Instructional and Motivational }}$ Classroom Discourse and Their Relationship with Teacher Autonomy and Competence Support-Findings from Teacher Professional Development. European Journal of Psychology of Education, 33(2), 377-402. https://doi.org/10.1007/s10212-016-0324-7 $\underline{(2)}$

Kusmana, A. (2011). E-Learning dalam Pembelajaran. Lentera Pendidikan: Jurnal Ilmu Tarbiyah Dan Keguruan, 14(1), 35-51. (1) (2) (3) (4) (5) (6)

Kusmiati, L., \& Rahadi, D. R. (2020). Pengembangan Kompetensi Mahasiswa di Masa Pandemic Covid-19. Jurnal Manajemen Bisnis (JMB), 33(2), 92-101. (1) (2) (3) (4) (5) $\underline{(6)}(7)$

Lembaga Administrasi Negara. (2018a). Peraturan Lembaga Administrasi Negara Republik Indonesia Nomor 10 Tahun 2018 Tentang Pedoman Pengembangan Kompetensi Pegawai Negeri Sipil (p. 108). Berita Negara Republik Indonesia Tahun 2018 Nomor 
1127.

Lembaga Administrasi Negara. (2018b). Peraturan Lembaga Administrasi Negara Republik Indonesia Nomor 12 Tahun 2018 Tentang Pelatihan Dasar Calon Pegawai Negeri Sipil. In Berita Negara Republik Indonesia Tahun 2018 Nomor 1800 (p. 108).

Martoredjo, N. T. (2020). Pandemi Covid-19: Ancaman atau Tentangan bagi Sektor Pendidikan? Jurnal Pendidikan, 2(1), 1-15.

Meo, P. De, Messina, F., Rosaci, D., \& Sarne, G. M. L. (2017). Combining Trust and Skills Evaluation to Form E-Learning Classes in Online Social Networks. Information Sciences, 405, 107-122. https://doi.org/10.1016/j.ins.2017.04.002

Momor, F. J., Rompas, W. Y., \& Tampi, G. B. (2020). Pengembangan Kompetensi Aparatur Sipil Negara di Kantor Camat Langowan Timur Kabupaten Minahasa. Jurnal Administrasi Publik, 6(92).

Munajatisari, R. R. (2014). Analisis Efektivitas Metode Pelatihan Tatap muka Dan ELearning. Jurnal Administrasi Bisnis Unpar, 10(2), 173-185. https://doi.org/10.26593/jab.v10i2.1463.

Mustaqin, H., \& Fahrina, A. (2020). Ketika Masyarakat Indonesia Bersatu Melawan Pandemi. Syiah Kuala University Press.

Mutia, I., \& Leonard. (2013). Kajian Penerapan E-Learning Dalam Proses Pembelajaran di Perguruan Tinggi. Faktor Exacta, 6(4), 278-289. (1) (2) (3) (4) (5)

Nadziroh, F. (2017). Analisa Efektifitas Sistem Pembelajaran Berbasis E-Learning. Jurnal Ilmu Komputer Dan Desain Komunikasi Visual (Jikdiskomvis), 2(1), 1-14.

Pujilestari, Y. (2020). Dampak Positif Pembelajaran Online Dalam Sistem Pendidikan Indonesia Pasca Pandemi Covid-19. Adalah, 4(1), 49-56.

Suartama, I. (2019). Development of an instructional design model for mobile blended learning in higher education. International Journal of Emerging Technologies in Learning, 14(16), 4-22. https://doi.org/10.3991/ijet.v14i16.10633

Suartama, I. K. (2014). E-Learning: Konsep dan Aplikasinya. Universitas Pendidikan Ganesha. (1) (2) $\underline{(3)} \underline{(4)}$

Sugiyono. (2011). Metode Penelitian Kombinasi (Mixed Methods). Alfabeta.

Sugiyono. (2015). Metode Penelitian Pendidikan (Pendekatan Kuantitatif, Kualitatif dan $\underline{R \& D) \text {. Alfabeta. }}$

Syarifuddin, M. (2020). Transformasi digital persidangan di era new normal (Issue 
October).

Uppal, M. A., Gulliver, S. R., \& Ali, S. (2018). Factors Determining E-learning Service Quality. British Journal of Educational Technology, 49(3), 412-426. https://doi.org/10.1111/bjet.12552 (1) (2) (3) (4) 